\title{
The Corrosion of
}

\section{Career?-Occupational}

Trajectories of Business

Economists and Engineers in Switzerland

\author{
Felix Bühlmann
}

Achievement careers are regarded as a distinctive element of the post-war period in occidental societies. Such a career was at once a modal trajectory of the modern parts of middleclass men and a social emblem for progress and success. However, if the achievement career came to be a biographical pattern with great normative power, its precise sequential course remained vague. Theories of the 1960s and 1970s described it as an orderly advancement within large firms. By the 1990s, scholars postulated an erosion of the organizational structures that once contributed to the institutionalization of careers, accompanied by a weakening of the normative weight of the achievement career by management discourse. We question the thesis of the corrosion of achievement career by analysing the trajectories of 442 engineers and business economists in Switzerland in regard to their orderliness, loyalty, and temporal rhythm. An inspection of types of careers and cohorts reveals that even if we face a decline of loyalty over time, hierarchical orderliness is not touched by those changes. Foremost, technical-industrial careers fit the loyal and regular pattern. Hence, this trajectory-type represents only a minority and is by far the slowest and least successful in terms of hierarchical ascension.

\section{Introduction}

Each historical period features its typical biographical patterns, left by the marks of the institutional setting through which the people move and the biographical choices they make within it. As Kohli shows, modernity-by means of demographic change, standardization of family cycles, and rationalization of work life-transforms the life course into a social institution in its own right (Kohli, 1985). It is on the backdrop of the institutionalization of the standard-biography that a series of class-bound 'modal trajectories' emerge (Bourdieu, 1979: 123). These models of biographical orientation are shared by milieus, gain normative force, and become part of the habitus of social actors. The achievement career can be seen as one of those class- and gender-bound modal trajectories. Its according habitus, fuelled by the search for individual mobility and social success, is chiefly widespread in the milieus of male qualified workers, commercial employees, and lower civil servants (Vester, 2001). As Vester points out for the German case, these members of modern middle classespecially the sons of the 'performance-oriented 
working-class milieu' and the 'modern employeemilieu'-are characterized by identities rooted in the future, letting them strive for a better future, for 'opportunities' and 'perspectives', that is, for an occupational position with more social prestige and rewards. In order to achieve this, they rely on educational credentials and the mechanisms of meritocratic status allocations, which they believe rewards everyone on the basis of their talent, know-how, and performance, and acts as motor of innovation and economic progress (Bourdieu, 1979).

Historically, the variety of such models of biographical orientation can be considerable. Some, though, come to dominate a historical period. I argue that the 'achievement career', in this sense, is of pre-eminent meaning for the post-war period due to a number of socio-structural changes from the 1890s to the 1950s. As emphasized by several influential authors of the 1950 s, the period was characterized by the strong numerical growth and simultaneous differentiation of the middle classes (Mills, 1951; Whyte, 1963 [1956]). As consumers and citizens, the middle classes thus became the centre of a wide range of commercial and political attention. Simultaneously, its internal structure changed fundamentally to the disadvantage of the traditional petty bourgeoisie such as shop owners and small entrepreneurs. The modern parts of the employed middle class-engineers, professionals, managers-increased in number, gained political force, and came to dominate the values, ideals, and aspirations of the middle class as a whole. Socially and economically, the modern parts of the middle classes, as the 'central constellation' of the post-war period (Mendras, 1988), 'constituted the most mobile and dynamic nucleus of the society, the principal utterer of values of modernity, of progress, of fashion and of success' (Castel, 1999: 587). ${ }^{1}$ They managed to impose their definition of success on large segments of society, not the least by their increasing control of public and political life (Boltanski, 1982; Castel, 1999).

This is why achievement career reflects the values and structures of a whole period and can be read as a kind of a seismograph of social changes thataccording to authors such as Sennett (1998) or Boltanski and Chiapello (1999)—have been shaking the system of post-war capitalism since the 1980s. In this perspective, I examine the sequential structure of achievement careers in Switzerland, try to identify some of its basic subtypes, investigate how it changed in the last decades and hope to understand better how these potential transformations reflect structural and normative changes of Swiss society.
In the first section, I define the achievement career and discuss three of its supposed characteristics. This is followed by a concise presentation of the structural and normative changes of the 1980s and 1990s and their presumed consequences on this type of career. Thereafter, I show that most of the sociological theories of the 1960s and 1970s struggled to adequately grasp careers and propose professional groups as an alternative research unit. In the fourth section, I illustrate how I applied this plan to empirical data and give full details about my methodological choices. Following is a general examination of these careers in regard to orderliness, loyalty, and temporal rhythms. In two subsequent chapters, I differentiate the analysis with respect to cohort and types of achievement careers. In the concluding section, I discuss the theoretical implication of the outcomes, suggest a series of possible explanations, and point out to methodological limits of the approach and sample.

\section{The Achievement Career and its Presumed Corrosion}

\section{Characteristics of Achievement Career}

As Spilerman (1977) indicates, the term career is either used in a prescriptive or a descriptive way. The prescriptive variety stresses the orderliness of the job sequence, whereas the descriptive use conceptualizes it simply as a work history, leaving its precise characteristics to empirical investigation. In this article, I want to test empirically if the work histories of a group of individuals with socially upward ambitions do or do not conform to some of the presumed characteristics of the 'achievement' type of job sequences.

The achievement career is a particular modern type of mobile job history in which the individual's job mobility is signalled by success, and the stages are ordered in a hierarchical pattern. Historically, achievement careers are intimately linked to the rise of large bureaucratic firms in the early 1900s. These new organisms were the hotbeds of upwardly mobile careers, replacing anterior trajectories often based on ascription and tenure (Stovel et al., 1996). Compared with its neighbours France and Germany, the Swiss public administration, since the foundation of modern Switzerland in 1848, was rather lean and had only minor influences on the establishment of differentiated and formally ruled private companies. As demonstrated by König et al., the development and standardization of achievement careers was due to the rationalization in the wake of the 'economic crisis' 
of the 1930s and to strategic company policies directed at the prevention of solidarization between workers and the arising-but already socially uncertainemployed middle class (König et al., 1985: 61-71).

After the war, large bureaucratic firms were celebrated not only as the new driving force of a flourishing economy but also suspiciously observed as breeders of new styles of working and living by sociologists (Mills, 1951; Whyte, 1963 [1956]). Their functionally and vertically differentiated structure, in combination with personnel policies securing fidelity (König et al., 1985), led to the construction of 'internal career ladders' or 'lines of progression' (Doeringer and Piore, 1971), which came to be the most important structural support for achievement careers. More generally, those internal career ladders were described as a part of a contract between the firms and their future management. The firms would promise their future manager long-term security and success, receiving in exchange loyalty, and a strong commitment. Three analytical elements have been assigned to the achievement career of the 1960s and 1970s: orderliness, loyalty, and temporal rhythm as marker of success.

\section{Orderliness}

Weber, in his theory of rationalization, stated that senior entitlement and meritocratical rewards resulted in incremental and regular occupational trajectories at the individual level (Weber, 1972 [1921]). Following Wilensky (1961), we may distinguish a functional from a hierarchical aspect of this idea: functionally, the jobs occupied by an individual are linked in the sense that an employee has to master a basic task in order to move to the next-more demanding-level. An illustrative example of this idea is the concept of 'line of progression' of Doeringer and Piore (1971: 58) in which 'work on one job develops the skills required for the more complex tasks on the job above it, and those at one point in the line constitute the natural source of supply for the next job along the line'. Hierarchically, senior entitlement promises jobs on the next higher level of organization to the most experienced and productive from the lower level, giving rise to slow but hierarchically incremental careers in the course of which individuals are steadily promoted to the next higher position.

\section{Loyalty}

In particular, scholars of the internal labour market (Althauser, 1989) suggested that achievement careers happened within one single large enterprise, with individuals being conducted securely through the different functions and hierarchical levels. Thus, they postulated not only that firms favoured internal careers by establishing career ladders but also that a majority of the employees effectively seized this opportunity. The unique promise of a combination of success, forseeability, and security would have had a strong appeal to young aspirants. In the 1950s, this kind of biographical orientation was caricaturedly sharpened by authors such as Whyte (1963 [1956]) in the thesis of 'Organization Man' as a 'historical deformation' of the enterprising and free American: "'Organization man" worked his way up through the hierarchical layers of the large corporation. Each step on the career path was planned and known in advance, loyalty to the organization being repaid by job security and steady progress up the corporate ladder' (Gunn and Bell, 2003[2002]: 190).

\section{Temporal rhythm as marker of success}

An achievement career does not merely mean to climb a ladder of hierarchically ordered occupational positions-the climbing is supposed to follow a certain temporal rhythm. For the employees of Lloyd's Bank, this means that 'early moves were keyed to subsequent moves, so that managers and clerks could assess their chances for promotion and act in accordance with these assessments' (Stovel et al., 1996: 392). In comparable terms, Wohlrab-Sahr states that one of the characteristics of a 'successful career' is: 'that the temporal structure of the biography itself-the timing of the stages, the continuity of the sequences-is perceived as 'biographical marker' leading to the attribution of success and becomes a referential condition for the success to come' (Wohlrab-Sahr, 1995: 234). ${ }^{2}$ In sequential terms, this would mean that especially quick hierarchical moves in the beginning of the career become essential for the recognition of 'talent' or 'potential' and are a precondition for moves to higher positions in the later years of the occupational trajectory.

\section{The Supposed Corrosion of Achievement Career}

By the 1980s, scholars observe quite a fundamental change of economic and organizational structures, echoed by a transformation of the normative discourse about work and occupational careers (Boltanski and Chiapello, 1999).

On the structural side, most Western economies faced an economic slow down by the mid-1970s and experienced additional crises in 1982-1983 and 1991-1993. This also affected the Swiss economy. The crisis of 1974 as an important recession causing a 
sharp deindustrialization, the depression of the 1990s as prolonged period of slowed-down growth completed by a further deindustrialization. The firms reacted with a reinforced shareholder-value orientation, with relocations, mergers, and acquisition strategies, and with internal restructuring (for an overview see: Honegger et al., 2002). For the first time since the Great Depression of the 1930s, this threatened a wider range of the active population: the unemployment rate jolted up to 5 per cent, and $>18$ per cent of the population experienced a shorter or longer period of unemployment in the 1990s (Honegger et al., 2002: 68). How do these changes affect achievement careers? In the literature, we first find evidence that the restructuring led to a contraction of the promotional space and a shortening of career ladders in an attempt to debureaucratize structures (Bouffartigue and Gadea, 2000: 93). Second, certain authors speak of a decategorization of work: clear-cut, vertical positions are replaced by polyvalent, amorphous, and rather project-oriented tasks that cannot be ordered anymore in hierarchical terms (Boltanski and Chiapello, 1999). Third, individualized assessment-systems, made possible by new performance measurement technologies, may accelerate the erosion of traditional promotion mechanisms, such as senior entitlement or incremental salary schemes, and contribute, therefore, to the destandardization of trajectories (Power, 1997). Fourth, the large bureaucratic enterprises willing to become 'lean' and more 'efficient' tend to outsource services they do not anymore consider as their corebusiness. In this way they contribute to the reduction of the share of large-scale companies and, therefore, weaken the institutional mechanisms supporting achievement career. ${ }^{3}$ Finally, their reinforced shareholder-value orientation may lead companies to abandon paternalistic_but financially 'irrational'protections policies for careers. This gives rise to new recruiting and dismissal policies and finally to an increasing share of 'broken ladders' (Osterman, 1996; Capelli, 1999).

This erosion of the structural foundation of the career has been doubled by a challenge of its normative bases by discourse of enterprises and management literature (Boltanski and Chiapello, 1999). Boltanski and Chiappello state that with the emergence of the post-Fordian lean and flexible firm, the promises of a secure and successful career have been replaced by prospects to participate in creative, stimulating, and enriching projects that overcome imprisoning boundaries (of enterprises, culture, or professions). As in the management discourse of the 1990s, 'flexibility' is the new fetish, as the new organizations are supposed to become fluid and constantly adapt themselves to changing demands, long-term security is no longer something they can offer their employees and future managers. Success is also changing its colour: it is no longer embodied by promotion in a 'paralysed' and 'mechanical' hierarchy but by the participation in a large network of relations. The management discourse highlights the adventurous and liberating character of a career as a succession of projects mounted with the help of relational resources. Others suggest that we assist to a pluralization of career promises, as a reaction to new forms of organizations (Dany, 2001). Aside from the traditional promise of a vertical achievement career and in order to dampen the clash between traditional aspirations and new realities, human resources managers would develop, for example, 'a promise of a subjective career, concerning internal horizontal mobility trajectories, through which middle management and certain professionals learn to find sources of satisfaction within positions not corresponding to traditional conceptions of success' (Bouffartigue and Gadea, 2000: 87).

What are the consequences of those structural and normative changes for the achievement careers on the three central dimensions of loyalty, orderliness, and temporal rhythm? Arthur and Rousseau (1996) suggest that the dominance of the 'organizational career' is increasingly replaced by the 'boundaryless career'. This new type of career is characterized by an increase in moves across firm boundaries and a series of extrafirm mechanisms intervening in the unfolding of the career. As a first hypothesis, (i) I expect, therefore, a decline in firm loyalty. Secondly, as a result of the combined effect of the normative pressure on career and the decategorization of work, I would attend that achievement careers include more and more horizontal moves or temporary downward moves. This would mean (ii) that the orderliness-understood as upwardly directed incremental career moves-is decreasing among the younger cohorts. Finally, the contraction of the promotional space and the organization of careers in form of a succession of projects would signify (iii) that a smaller proportion of career candidates' moves to higher positions or that their rise is significantly slowed down.

\section{Bringing Professional Groups Back In?}

Before setting about these hypotheses, I must clarify the research strategies by which achievement careers can be approached. Careers have been tackled by at 
least two angles: on the one hand, a sort of an affix of social mobility research; on the other, a pivotal concept of symbolic interactionism.

The scholars of the individual approach of social mobility (Blau and Duncan, 1967), even though interested in intra-generational mobility, were focussing on absolute changes of mobility rate and, following the popularization of path analysis models, on the factors predicting mobility. As a result, career was reduced to a comparison of the first and the actual occupation, the linkages between jobs, and the sequential nature of careers being widely ignored (Spilerman, 1977; Abbott and Hrycak, 1990). The internal labour market research, a part of the 'neostructuralist approach' emerging in the late 1970s, demonstrated the necessity to study stratification and mobility on an organizational meso-level (Baron and Bielby, 1980) and, therefore, focused on the study of single firms and sometimes of samples of firms (for an overview: Althauser, 1989). In contrast to most of the status attainment research, this kind of approachbased either on stochastic models (Rosenbaum, 1979), optimal matching analysis (Stovel et al., 1996), or ethnographic material —was able to conceptualize the sequential nature of trajectories more convincingly. On the other hand, with those scholars turning their attention to single firms and their career models, it might have given the research on careers a turn thatby the accumulation of studies-has led to a problematic contraction of scope. As they oftentimes focused on ideal typical large and bureaucratic firms, they perhaps overestimated the importance of loyal careers shaped by bureaucracy and lost sight of the careers including shifts between firms or economic sectors.

A promising alternatives are the studies of particular professions or occupations, popularized by researchers of the symbolic interactionist school in the 1950s and 1960s (Becker, 1952; Becker and Strauss, 1956). These sociologists were successful in linking the institutional setting to the individual career, and we owe them also for a great number of insights on career mechanisms, based on ethnographic studies of professionals. However, they rarely thought to link their studies to broader considerations of social stratification and mobility, being more interested in the particular issues at stake within those occupations. Nevertheless, career studies based on specific professional groups can be linked to questions of social mobility and would allow overcoming of some of the biases introduced by the internal labour market approach. By focussing on individuals rather than career arrangements, I can observe their moves through different enterprises and economic sectors (Abbott and Hrycak, 1990), as well as the differentiation of career over time. This is of crucial importance if I want to examine the supposed erosion of orderly organizational careers within one single enterprise. Literature on single organizations included oftentimes all the jobs within one firm (Althauser, 1989) and thus had to deal with a great heterogeneity of different types of biographical projects and careers. In this respect, studying professional groups allows one to focus more specifically on a certain type of careers as occupations or professions are structurally linked to a quite narrow choice of possible trajectories. This is because the choice of profession, as a highly identity-bound decision, reflects the orientations and values of the individual's social milieu, and translates its plans and projections towards the future. This is why I argue that the construction of the sample based on educational choices allows me to choose individuals with a specific social identity and a particular relationship to the future. Specifically, in order to study achievement careers, it should be possible to separate those individuals with an aspiring habitus by examination of particular 'career professions'.

I put this program in practice by choosing two professional groups that play a crucial role for the utopia of generalized upward mobility. First, I have to choose the functions displaying an elective affinity with careers: according to Schnyder et al. (2005), the majority of Swiss managers and economic leaders hold a degree in engineering, economy, or law. Because the importance of the latter has declined rapidly since the 1980s (Barrial, 2006), I will concentrate on the occupations of engineers and business economists. Both of these are typical male-dominated careerprofessions, the first as the pivotal occupation of the industry, the second as all-round managerial profession of the service sector. Second, in Switzerland, the two professions happen to be among those which can be learned by the path of 'Higher Occupational Schools'. This means that this group first attends an apprenticeship-either in a technical or a commercial occupation-and then, usually after some years of work, returns to Higher Occupational School in order to launch an upward career. The decision to attend Higher Occupational School involves a big sacrifice in terms of time, energy, and money and is thus not only a verbal but also a practical and very reliable proof of their upward ambitions. Additionally, in post-war Switzerland, the 'educational expansion' did not focus on the democratization of the access to university (as in Germany or in France) but consisted of a qualitative and quantitative strengthening of the Higher Occupational Schools supposed to promote 
Table 1 Composition of the sample in regard to gender, cohort, and employment status (\%)

Engineers

FH Schweiz Swiss federal census
Business economists FH Schweiz Swiss federal census

\begin{tabular}{lcccc}
\hline Gender & & & & \\
$\quad$ Men & 98.8 & 96.7 & 79.9 & 68.0 \\
Women & 1.2 & 3.3 & 20.1 & 32.0 \\
$\quad 50+$ & 34.2 & 35.8 & 9.6 & 25.3 \\
Cohort & & & 32.1 & 29.0 \\
$\quad 40-50$ & 37.9 & 29.2 & 58.2 & 45.6 \\
$\quad 30-40$ & 28.0 & & & 86.9 \\
Employment Status & & 79.9 & 91.6 & 13.1 \\
$\quad$ Employed & 85.1 & 20.1 & 8.4 & \\
$\quad$ Self-employed & 14.9 & $200)$ & \\
\hline
\end{tabular}

Source: [FH Schweiz-survey (2005) and Swiss federal census (2000)].

and generalize the rise from the 'bottom' to the 'top' (Meyer and Ryter, 1993). The recruitment-pool of that educational curriculum thus corresponds quite exactly to the milieu described by Vester (2001) as upwards oriented: qualified workers, commercial employees, and lower-civil-servants are highly overrepresented in comparison to other milieus. ${ }^{5}$

\section{Data and Methods}

\section{Sample}

The data stems from a self-administered, calendared questionnaire that has been joined in August 2005 to the tri-monthly journal of the Association 'FH Schweiz', the association of the graduates of Higher Occupational Schools, counting about 27,000 members. Following the exclusion of members of other professions than business economists and engineers, Italian speakers, and those with an occupational period shorter than 10 years, 5,000 interviewees have been chosen by systematic sampling techniques. The return rate, in spite of a supplementary reminder by e-mail, remained at 9 per cent $(N=442)$. This low rate is due to the postal form of the survey, but as well to the fact that the targeted group is particularly busy 'making career' and lacks the time and energy to fill in such a questionnaire. Supposedly, the unusual, calendared form of the questionnaire has further contributed to the low rate. In order to gain a more adequate picture of the representativeness and the quality of the data, I compared it to data about the two professions from the Swiss Federal Census 2000.

Table 1 demonstrates that engineers are fairly well represented in the FH Schweiz-Survey; only the self-employed are slightly underrepresented. However, the situation is not so bright when it comes to business economists: first, women are underrepresented in the FH Schweiz-Sample. ${ }^{6}$ Even more seriously, due to institutional reforms of the Higher Occupational Schools in the 1970, business economists over age 50 are underrepresented while the youngest cohort of business cohorts is overrepresented. ${ }^{7}$ Even though business economists are today a rather young profession in Switzerland, these differences become an obligation to interpret the results carefully, particularly with respect to cohort and age. In spite of these slight discrepancies, I argue that the depth and homogeneity of the sequential data compensates of the FH Schweiz for some of its shortcomings.

\section{Variables}

The questionnaire covered both the educational trajectory and the occupational trajectory. In particular, the interviewees were asked to note each of their occupational stages by indicating the beginning and end of the stage, the economic branch in which they worked, the internal function they occupied, their occupational position, and the size of the company. Each of these four dimensions then has been coded in a way that subsequently allows me to grasp the significant patterns of their sequential order. I divided the economic branch into the following categories: 'Industry', 'Building', 'Personal and Public Services', 'Banks and Insurances', 'Services to Enterprises', and 'Non-Employment-Periods' (e.g. mainly education periods). In this way, I differentiate between branches with high productivity (banking and services to enterprises) and branches with lower productivity, such as industry, building, or personal services. As to 
the internal function-the department or division in which the individuals work-I distinguish between 'Production', 'Research, Development and Planning', 'Marketing and Sales', 'IT', 'Human Resources', 'Allround Administration', and 'Finance and Controlling'. The occupational position is the only one suiting a clear-cut hierarchical pattern and, therefore, enjoys a central role in the reflection. I discriminate between 'Employees', 'Lower/Technical Management', 'Middle Management', 'Upper Management', and 'SelfEmployed'. Finally, in order to get a proxy of the type of enterprises, I coded them according to their number of employees. This resulted in the following four types of enterprises: 'Micro-enterprises' (0-10), 'Small Enterprises' (0-50 employees), 'Middle Enterprises' (50-250), and 'Large enterprises' (250+).

\section{Indicators}

To examine the orderly character of careers, I take up the operationalization of Wilensky (1961). He distinguished between functional and hierarchical orderliness. As I am particularly interested in the hierarchical orderliness of trajectories, I refined the coding of the occupational position and grouped the shifts within this dimension in the following four categories: 'orderly upwards shifts' (to the next higher level), 'skipping upwards shifts' (to the next but one higher level), 'downwards shifts', and 'changes from salaried employee to self-employed or the reverse'. A glance at the overall sample shows that almost two-thirds of the hierarchical job-shifts are of orderly nature; that is, a hierarchical upwards steps from one level to the next higher. Only about 15 per cent each of the changes are skipping step upwards or downwards slides, and $<10$ per cent are shifts between salaried and selfemployed. In order to synthesize the indicator and to make it applicable to the individual level, I created in a second step a ratio indicating the relationship between orderly and non-orderly shifts (skipping upwards, downward slides, and changes to and from selfemployment). To prevent biases due to differential length of careers, I weighted both sides of the ratio by the number of years of employment after graduation. Overall, this ratio yields a proportion of 83 per cent of orderly shifts. Loyalty is measured by the number of enterprise changes, counted from the year of graduation onward. According to the number of shifts they made during their occupational trajectories, I coded the persons in the following four categories: 'No change', 'one change', 'two to three changes', and 'four or more changes'. The data display that only 8 per cent of the population never changed their employer, 16 per cent changed one time, 49 per cent two to three times, and an astonishingly 27 per cent four or more times. For subsequent analysis, I weighted the indicator by the number of years of employment to obtain comparable values.

'Success' is measured by the percentage of individuals attaining lower/technical management, middle management, and higher management. In order to relate this indicator to the temporal rhythm, I also indicate the average age at which these transitions occur. An overview displays that 77 per cent of the sample reaches lower or technical management, 58 per cent moves to middle, and 32 per cent to upper management. In addition, these hierarchical levels are chronologically ordered. The higher the hierarchical level, the higher the average age of attainment.

\section{Analytical Strategy}

To answer the research questions, this general overview must now be differentiated. The sampling strategy based on an 'aspiring habitus' (expressed by the choice to go back to Higher Occupational Schools) allows me to observe the biographical unfolding of achievement careers. This is why I can now observe the development of a series of career subtypes that, as I postulate, differ quite fundamentally with respect to orderliness, loyalty, and temporal rhythm. In order to grasp these potential differences, I will reduce the complexity and variety of the individual careers by grouping them into a small number of clusters. Therefore, I apply a multichannel optimal matching analysis to the data, which discriminates different types of trajectories with respect to sequential order.

In the second step, I am going to compare orderliness, loyalty, and temporal rhythm in regard to three cohorts. This allows me to address the postulates of the corrosion of the achievement career-thesis, declining orderliness, and decreasing loyalty. In addition, this will shed some light on the interdependence of those supposed changes on all three dimensions and the possible mechanisms of mutual influences between them.

\section{Typical Careers and their Characteristics}

\section{A Typology of Achievement Careers}

Ever since Weber, typologies are one of the privileged tools of analysis and description in social sciences. Thanks to typologies, we are able to reduce and 
Table 2 Duration indicators by types (Average length of stay in position in years)

\section{Education Employee Lower Middle Higher Self- Total management management management employment}

\begin{tabular}{|c|c|c|c|c|c|c|c|}
\hline $\begin{array}{l}\text { Financial- } \\
\text { banking }\end{array}$ & 2.12 & 4.87 & 6.22 & 2.22 & 1.15 & 0.31 & 17.12 \\
\hline $\begin{array}{l}\text { Technical- } \\
\text { industrial }\end{array}$ & 3.08 & 4.39 & 10.55 & 3.29 & 0.37 & 0.08 & 21.76 \\
\hline Service Staff & 2.87 & 4.62 & 5.29 & 4.33 & 2.28 & 1.24 & 20.74 \\
\hline $\begin{array}{l}\text { Industrial } \\
\text { management }\end{array}$ & 2.80 & 5.32 & 5.64 & 3.69 & 1.57 & 0.25 & 19.32 \\
\hline Small/middle firms & 2.17 & 3.9 & 7.00 & 4.20 & 2.90 & 3.27 & 23.44 \\
\hline Financial & 3.12 & 4.35 & 2.90 & 5.15 & 3.47 & 0.18 & 19.18 \\
\hline
\end{tabular}

Source: [FH Schweiz-survey (2005)].

structure complex realities into a small number of groups or concepts that facilitate theory building (Kelle and Kluge, 1999). Optimal matching analysis is a method particularly well suited to describe sequential data. It allows us to reduce the overwhelming variety of occupational trajectories and thereby to understand their stages, chronology, and pattern of changes (Abbott and Hrycak, 1990; Aisenbray, 2000). The following analysis relies on the multi-channel technique, developed by an interdisciplinary team of researchers at the 'Pavie Center' of the Universities of Lausanne and Geneva (Gauthier et al., 2008a,b). This new method makes it possible to take into account several dimensions for the construction of the typology. I based the analysis on the following four dimensions: economic branch, functional unit, occupational position, and type of enterprise. The attribution of costs of substitution and deletion is derived from a theoretical model developing specific solutions to each of the four dimensions. ${ }^{8}$ I applied a wardclustering procedure to the distance matrix produced by the optimal matching alignment algorithm. Compared with other types of clustering procedures, it generally produces a small number of clusters with a relatively even size. The six-number solution, I finally chose has been determined by the stopping rules elaborated by Milligan and Cooper (1985).

In the following lines, I will present these six types: Financial-banking-careers, Technical-industrial careers, Service-staff-careers, Industrial management careers, Small- and middle enterprise-careers, and Financial careers. In a first step I am going to present the table of the duration indicators (Table 2) of the occupational position-the most central of the four dimensions-and in a second step I will shortly describe each trajectory-type and its sequential course on the dimensions of economic branch, functional unit, occupational position, and firm size.

\section{Financial-banking career $(n=74,16.8$ per cent)}

This type of trajectory takes place in large banking and insurance companies and to a lesser extent in firms of related service sectors, as personal services and services to enterprises. Of all career types, it is the most firmly rooted in the universe of large enterprises-changes to middle or even small-size companies are virtually excluded. The group, largely dominated by business economists (95 per cent), works mainly in accounting and controlling; a minority in marketing. Compared with other types, change of functional unit are rare, the majority remaining true to financial tasks throughout their career. A glance at the hierarchical dimension reveals that the members of this cluster remain relatively long in positions of lower management ( 6.2 years), but compensate for this by a relatively quick bridging of middle management position.

\section{Technical-industrial career $(n=38,8.6$ per cent)}

The members of this cluster stay exclusively in the industrial sector, working either in production or the research departments of large-scale firms. It is thus no surprise that it involves almost exclusively engineers (95 per cent). If a glance at the functional subtrajectories and the related change-coefficient points to a quite high level of fluctuation, a closer examination though shows that these changes occur chiefly between research and production. The technical-industrial career is by far the slowest trajectory-type: after about 4 years as employees, these engineers move to positions of technical or lower management, where on average, they remain $>10$ years. Accordingly, only a 
few of them are promoted to middle management or upper management.

\section{Staff career in the service sector}

( $n=97,22.0$ per cent)

This is the most heterogeneous trajectory-type, which does not correspond to an intuitively recognizable pattern. Even if business economists prevail numerically ( 57 per cent), it is also open to engineers ( 43 per cent). On all dimensions, relatively high coefficients of change can be observed, which means that this group often changes between branches, functional units, and even types of enterprises. About the half of the group advances in middle or small enterprises. A majority works in the personal or public sector services, shifting between personnel, sales, and IT-tasks we can resume as staff functions supporting the production units. On average, they work 4.5 years as employees, 5.2 years in lower management positions, 4.3 years in middle management, and $>2$ years in higher management.

Industrial management career

( $n=75,17.0$ per cent)

This trajectory-type compasses on the one hand engineers (57 per cent) who, subsequent to their beginning in the traditional functions of production or research in large industrial firms, leave those domains in order to move to marketing, IT, or finance within the industrial sector. A second subgroup is composed of business economists ( 43 per cent) working in the service functions of large industry, respectively, in the personal and public service sector. Moves to middlescale (and sometimes even small-scale) firms in the course of the trajectory are possible. Compared with the technical-industrial career, they spend about the same period in employee status (5.3 years on average), but bridge much more quickly the lower management zone. On average, they remain 5.6 years within this level and then move to middle management positions.

\section{Career in small and middle-scale firms}

( $n=30,6.8$ per cent)

This bundle of careers differs from all the others. Its universe is limited to the middle and small firmsonly about 15 per cent of those trajectories pass through large enterprises. Throughout their careers, the members of this cluster work almost exclusively in the construction branch, either in research and planning or in a production unit. Thus, we can speak of a sort of 'construction-career' of planners and self-employed entrepreneurs (93 per cent engineers). As the position of middle and higher management assumes quite a different meaning in the context of small enterprises, a direct comparison with the other types in terms of hierarchical achievement hardly makes sense. We can observe, though, that a large proportion reaches a position as a general manager of those small firms or found a firm themselves.

Financial career ( $n=91,20.7$ per cent)

This type of career is strongly dominated by business economists (95 per cent). In contrast to the Financialbanking-career, it is relatively independent of the economic branch, embracing at the same time careers in industry, banking, or services to enterprises. Instead, it is deeply rooted in finance, controlling, and accounting. A minority works also in marketing and sales for certain periods. This type of career is not bound to large enterprises; about 40 per cent are employed in middle and small enterprises or switch between large and middle-scale companies during their career. Members of this type remain on average 4.3 years in employee positions and pass very quickly through positions of technical and lower management (2.9 years).

\section{Results of the Typological Analysis}

In the following section, I will relate the six types of careers to the indicators of orderliness, loyalty, and temporal rhythm by a test of the differences between means (Table 3 ).

The industrial research-career, in particular, but to a lesser extent also the financial-banking career, is strongly dominated by hierarchically orderly moves. All the other types of careers are significantly less orderly, especially the staff-career in the service sector, the small-enterprise-career, and the financial career. The technical-industrial career, together with the career in middle and small enterprises, is also one of the most loyal ones. The remaining career types are significantly less loyal, the financial-banking career and the industrial-management standing out as trajectories with a large number of firm shifts. With the exception of small-enterprise-careers, where 'higher management' has a different meaning (in terms of power or span of control), I am also able to compare career-types in terms of success. Particularly technical-industrial career and the financial career stand out: the first is signalled by only few and rather late moves to the middle and upper levels of management. The financial career, on the other hand, is the most successful and the fastest track, as over 50 per cent reach upper management at a relatively young age. Quite systematically, the age of attaining a certain hierarchical level is linked to the 


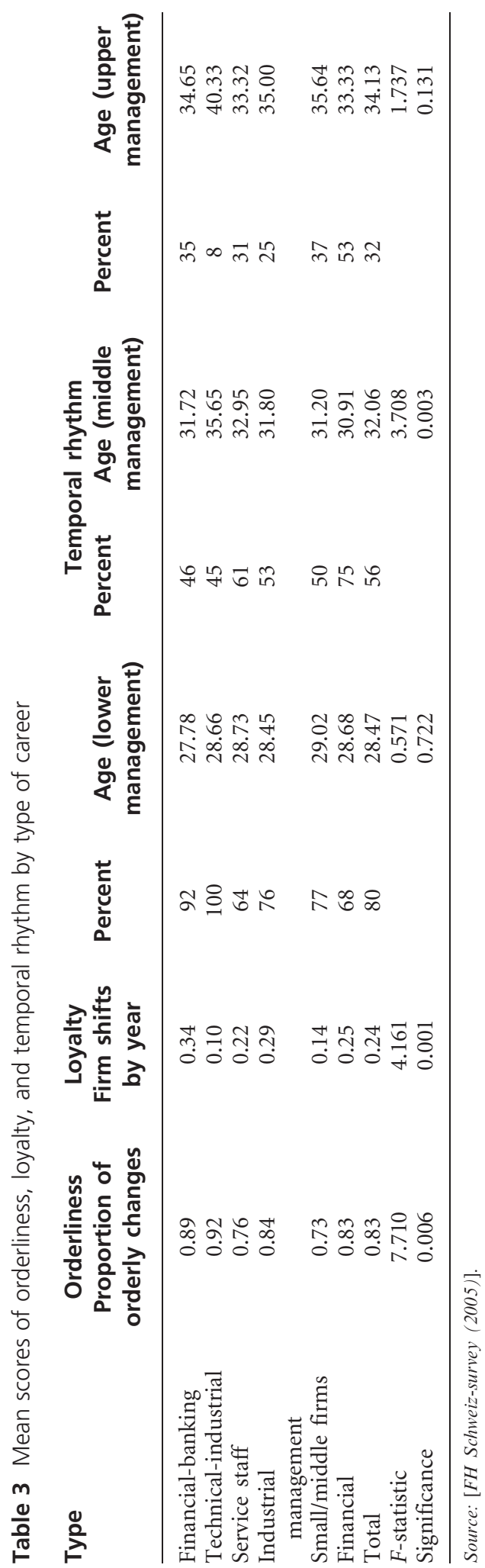

success score of careers. All other careers are inbetween those two types. Conspicuously, financial careers are less successful in the banking and insurance sector where merely 17 per cent of the individuals reach higher management at a slightly more advanced age than in the 'general' financial career-type.

\section{Biographical Dynamics in Historical Contexts}

\section{Differences According to Cohorts?}

In this section, I look at historical alterations of orderliness, loyalty, and temporal rhythm of career by expanding the analysis to birth-cohorts. I distinguish between those born before 1955, those born between 1955 and 1965, and those born between 1965 and 1975. The coding of the cohorts has been inspired by an analysis of the dynamics of the socio-economic context in Switzerland (Levy et al., 1997; Honegger et al., 2002).

As in the majority of Western countries, in Switzerland, the 'petrol-shock' of 1974/1975 signified the beginning of the end of the post-war 'golden age'. But even if this first depression caused a general economic slow-down, its consequences were rather mild compared with other countries-at least for those working in the primary labour markets. Switzerland reacted to the recessions of 1975 and $1982 / 1983$ by forcing foreign workers to re-emigrate to their countries of origin and by pushing the female labour force out of the market (Levy et al., 1997). Furthermore, the depression of the 1970s did by far not affect the totality of economic branches in the same way and with the same force. Export-oriented branches, particularly watch-industry and machineindustry, were severely hit, while other core-branches of Swiss economy as banking or pharmaceutical industries partially escaped the slump (Levy, 1997). Therefore, good-educated men of the cohort born before 1955 may have been well aware of the subdued mood in the years of their early careers. Structurally, however, they were one of the last cohorts of the postwar golden age, living the crucial periods of their careers in a context resembling the 'trente glorieuses'. At the time of the 1991 depression, as a consequence of their career-progression, they probably already occupied positions that protected them against restructuring or even made them leading actors of the organizational restructuring.

This changes dramatically for the two following cohorts: the career candidates born between 1955 and 
1965 have never experienced the spirit of the 'golden age' in their youth and were not equipped with the same optimistic hopes of progress and upswing as their older colleagues. Besides, they faced the depression of the 1990-which, with its merger and acquisitions, its organizational restructuring and its reinforced shareholder-value orientation, also affected the primary labour markets-in the early and crucial years of their careers (between 26 and 40 years). The cohort of 1965 to 1975 as a third subgroup may have already grown up with the discourse of flexibility and the pluralization of career promises. More than the two older cohorts, they have interiorized alternative definitions of success and the new promises of self-fulfilling and adventure. And of course, they entered the labour market at a moment when, by the profound restructuring of the banking and industrial sectors (Honegger et al., 2002), flat hierarchies, teamwork, and projectoriented management were already popular in the Swiss corporate world. Therefore, their careers developed right from the beginning under a completely different star.

\section{Results of the Cohort Analysis}

With this distinction of cohorts at hand, I am now able to re-evaluate the indicators of orderliness, loyalty, and temporal rhythm (Table 4).

Careers of engineers and business economists born before 1955 are not more orderly than those of individuals entering occupational life in the 1980s and 1990s. In opposition to orderliness, the number of changes in the firm-shift dimension evolves quite radically over time. The careers of members of younger cohorts are much less loyal than those of their older colleagues. Conspicuous is not only the decline itself, but also the particular speed of the trend: the proportion of firm-shifts doubles with each cohort, from 0.1 shifts per year for the oldest to almost 0.4 for those born between 1965 and 1975. The analysis of the aspect of temporal rhythm is to be handled carefully. It is statistically significant, but difficult to control and interpret. Both proportion of attainment and average age are probably biased by the fact that a certain number of the interviewees of the younger cohort have not yet achieved upper management.

\section{Discussion}

I assumed that graduates in economics and engineering constitute an adequate sample of individuals with an aspiring habitus, willing to 'make career' by exploiting the opportunities, and structures offered by the firms.

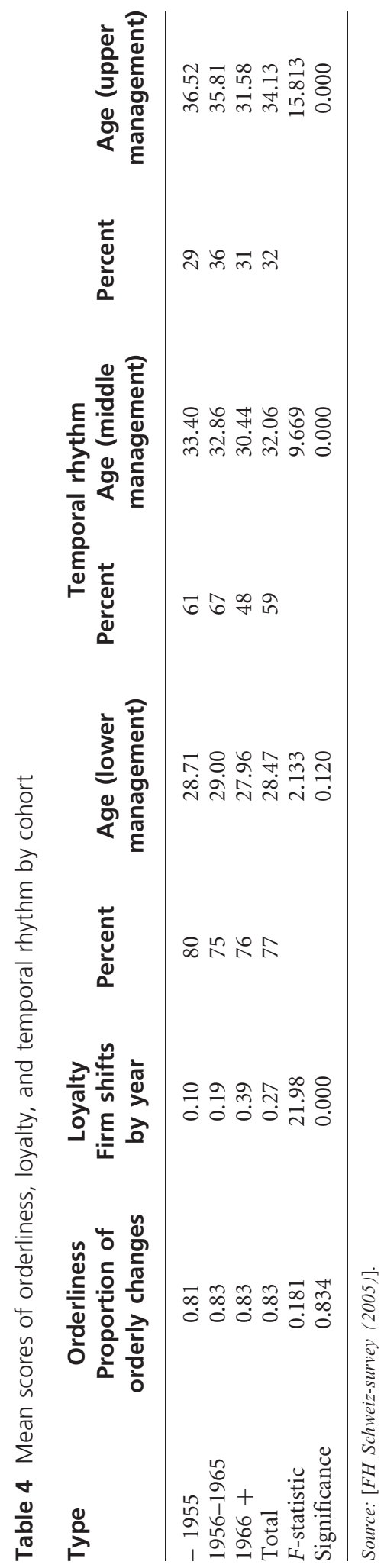


The outcomes indicate that often their wishes come true. Generally speaking, they experience a quite orderly and loyal career, chronologically structured, and crowned by promotion to middle or upper management. Yet, only a deeper analysis by type and cohort uncovers the biographical and historical contingencies and the mechanisms steering these trajectories.

\section{Anchors and Structures}

Analysis by types reveals that achievement careers cluster in six groups. Engineers make either career as developers in large industry firms, as planers in small bureaus, or as managers in large industry firms. In many ways the technical-industrial career stands out as the archetype of a loyal and orderly career. As the only one of the six types, it features high values of orderly upwards movement and low numbers of firm shifts. It almost perfectly fits the picture of the 'organization man' drawn in the 1950s. However, the group represents only a small minority. In addition, it is by far the least successful and the slowest career. In fact, this is the only one whose members do not move to middle and higher management in substantial proportions. But these 'career-brakes' are probably not exclusively structural. Recent Swiss findings indicate that engineers often have a technicistic conception of personal, entrepreneurial, and social progress, resulting in a sort of distrust towards the commercial management of industry and their 'economic' logic of work and progress (Honegger et al., 2002). In this case, a move to a higher (often commercial) level amounts to 'running over to the enemy'. Strong identity anchorsas here the technical conception of progress-can thus contribute in an interplay with structural reasons, to the 'failure' or 'success' of achievement careers.

\section{Breaks and Success}

To compare loyal and regular careers, it is now insightful to cast a glance at another type of technical career and its underlying mechanisms: the members of the industrial-management type are to a large extent engineers who quit the technical domain in the direction of more managerial tasks (human resources, marketing, or finance). Interestingly, their careers are characterized by breaks on different dimensions: their outbreak of the technical domain involves more shifts between firms and they face also more 'non-orderly' career-steps. In the long run, however, those who 'break out' attain higher management in considerably higher proportions and at a younger age than purely technical engineers. Under certain circumstances, accepting a horizontal move or a temporary downgrading can thus pay off in the form of more vertical success. In comparison to trajectories of business economists though, and especially finance-oriented business economists, these industrial-managementcareers are still significantly slower and less successful. A possible explanation is that by 'running over', engineers have to readapt to tasks they were not formed for and lose crucial years in their technical functions compared with those who are on the successful financial track right from the beginning. In addition, the connections to the technical domainor at least to industry-remain strong and seem to confine the choices of these engineers as to economic branch and function.

\section{Functional Fast Tracks}

The particular status of financial functions is conspicuous. Both financial-oriented career types are particularly quick and successful. Additionally, we observe a specific pattern of shifts and loyalty common to those careers. Whereas these individuals shift easily between firms or economic branches, they stay more faithful to their function than all other types. It seems that financial functions facilitate the shifts between branches and firms and, therefore, serve as a privileged channel to the top. There are two reasons for this: first, financial knowledge and experience might be less firmbound or branch-bound than other specializations. It corresponds increasingly to a 'professional knowledge' with a relatively high standardization of knowledge across contexts, positions, and branches. Second, the rise of multidivisional ever since the 1960s (Fligstein, 1987) and the growing centrality of shareholder-orientation (Capelli, 1999), that brought a sort of a 'financial turn' to the corporate world in the 1990s, grants financial functions a pre-eminent status and facilitates structurally successful careers. What are the differences between the two types of financial careers now? Pure financial careers are less orderly, more loyal, and by far more successful than its sister careers in the banking and insurance branches. These individuals also shift more often between different branches and different types of enterprises. Even if this causes an increase of non-orderly changes, in the long run-as they do not involve a functional reorientation and are supported by the transferability of financial knowledge-it pays off. Financial-banking careers, on the other hand, stand out by the simultaneity of a high orderliness and high-rates of firm shifts. It seems as if financial-banking careers are 'closed in' in one sector, 
ruled by relatively homogeneous mechanisms of recruiting and promotion.

\section{The Loosening Link between Loyalty and Orderliness}

A look at the result of the cohort analysis shows that loyalty falls markedly and rapidly over time. Fidelity was still quite widespread in the cohort entering the labour market in the early 1970s. Their values of loyalty correspond quite exactly to those of the technical-industrial career. Yet, it was only in this domain that the patterns of a loyal career remained in force. Surprisingly, and in this point counters the hypothesis of the boundaryless career, the decline of loyalty is not followed by a decline of orderliness. This means that orderliness is not functionally and necessarily coupled with loyalty. Coherent and continual organizational structures or uniform personnel policies are apparently not the only way to produce promotional orderliness. I can think of several reasons for this phenomenon: first, in certain economic sectors, firms are organized in a quite homogeneous and standardized way, which enables them to 'collectively' practice policies, which do not fundamentally differ from internal firm policies. Second, I assume that the continuity of orderliness is also due to individual strategies of the actors involved. In spite of (or even because of) an increase in changes between firms, they rely on a series of biographical norms conceptualizing occupational trajectory as an orderly upwards movement. As a result of normative self-control, the individual would thus try to avoid downward mobility and too steep upwards movement. It is as though a formerly structural mechanism is replaced by an individual strategy, which itself is a normative legacy of historical anterior structures.

\section{Limits of Approach and Sample}

These results have to be treated carefully. They concern only a particular group of upward-oriented individuals and, therefore, wider enquiry on the impact of demographic changes on mobility and careers would be welcome. Particularly, the changes brought about by the academization of certain parts of the labour market-for example the banking sector (Barrial, 2006) - should be integrated more consequently in the analysis in order to evaluate the social meaning of the trajectories of Higher Occupational School diploma holders. Second, an analysis based on a larger and more solid sample would be highly desirable to confirm (or infirm) the results beyond the relatively explorative status they have for the moment. Such a larger sample would allow for more solid subgroups, more appropriate for further, multivariate analysis.

\section{Notes}

1. Translated by the author.

2. Translated by the author.

3. Levy et al. show that in Switzerland for the first time since 1920, the share of companies with more than 250 employees begins to decline in the 1980s and 1990s (Levy et al., 1997).

4. The Swiss education system is comparable to the German model, based on the dual apprenticeship. About two-thirds attend an apprenticeship, $<20$ per cent go to university. Under certain circumstances (complementary degrees, some years of occupational experience), the graduates of an apprenticeship have the opportunity to attend a 'Higher Occupational School' (Fachhochschule or Haute école spécialisée). This educational path enables foremost commercial and technical employees to upgrade their apprenticeship by acquiring the diploma of an engineer or business economist, which is supposed to facilitate ascension to middle management.

5. Recent comparisons of the social background of University versus Higher Occupational Schools students demonstrate that if we cast a glance at men, only 18 per cent of the HOS-students have hat least one parent with a university degree whereas it is 36 per cent for university students. On the other side, 42 per cent of the HOSstudents have at least one parent with an apprenticeship (or another post-obligatory education) versus 33 per cent for university-students (Boegli et al., 2007). These are values of 2005, the results of the FH Schweiz-Survey, however, indicate that the difference have been greater in the past. Here only 6 per cent of the engineer's parents and 9 per cent of the economist's parents have a university degree.

6. This might be due to the fact that women because of their 'objectively' lesser chances to make career, are also less interested in career and, therefore, participate to a lesser degree in surveys about careers. This under representation is not a very 
large problem, as I am mainly interested in the achievement career as a male institution.

7. In the beginning of the 1970 s, a certain number of prior, privately sponsored forms of businessoriented Occupational Schools have been transformed into state-sponsored Higher Occupational Schools. The graduates of these anterior forms of Higher Business Schools do not appear in the FH Schweiz-Sample, while they are included in the census data.

8. The attribution of substitution and deletion cost is decisive to optimal matching analysis (Abbott and Hrycak, 1990; Aisenbray, 2000; Gauthier et al., 2008a). They are most often set on the ground of theoretical reflections and determine the ease by which one sequence can be transformed into another; i.e., which sequences are finally grouped together by the cluster mechanism. The relationship between substitution and deletion costs and the differentiation of substitution cost accordingly between the dimensions of our occupational trajectories are particularly determinant. The sample contains sequences of various lengths, as the individuals studied are at different stages of their career. These differences have been reduced by excluding careers shorter than 10 years and by limiting our analysis to the first 25 years of the occupational trajectories. Nevertheless, the still different lengths pose problems because the lengthsensitive algorithm of optimal matching tends to class sequences according to their duration. By setting the insert and deletion costs at the minimum of the substitution cost, this difficulty can be minimized. Therefore, I set the insertdeletion costs at 0.5 in all four 'channel-matrix'. While this approach contrasts with most of the historical optimal matching studies having full length sequences at hand (Abbott and Hrycak, 1990; Stovel et al, 1996), virtually all contemporary studies using sequences of different lengths adopt this kind of strategy, too (Widmer et al., 2003). The second aspect concerns the substitution cost between the positions. I have elaborated a theoretical solution for each channel: the economic branches have been divided in a production-sector encompassing industry and construction and a service sector made up of personal services and services to enterprises and banking/insurances. I set substation costs to 4 for changes between the sectors, whereas changes from one branch to another within the sectors are counted by 2 . In the same way, the cost model of the internal function is not hierarchical in nature but reflects rather horizontal differences. I put together the three service functions sales/marketing, IT, and human resources, the two technical functions production and research and development by attributing to them a change rate of two. All the other functions stand alone. The cost for a change between one of those sub-groups has been set at 4 . The centrality of the occupational position for our research questions allowed me to set the costs for changes higher in this dimension in order to give it a greater relative importance. Substitution costs were set at steps of four between the hierarchical occupational position levels $(4,8$, and 12) and at 6 between selfemployment and all the other positions. Finally, the small and micro enterprises were grouped together as opposed to the middle and large enterprises. The substitution costs mount at 2 within and at 4 between the two subgroups.

\section{Supplementary Data}

A graphical presentation of the career types can be viewed online on www.esr.oxfordjournals.org. The data for these graphs stem from the FH Schweizsurvey (2005).

\section{Acknowledgements}

For their valuable comments I am grateful to Eric Widmer and René Levy and to the anonymous reviewers of the ESR. I thank Jacques-Antoine Gauthier for his assistance concerning multi-channel optimal matching, Dominik Etienne for the dataacquisition, and Jean-Claude Ziswiler for the programming of the indicators.

\section{References}

Abbott, A. and Hrycak, A. (1990). Measuring resemblance in sequence data: an optimal matching 
analysis of musicians' careers. American Journal of Sociology, 96, 144-185.

Aisenbray, S. (2000). Optimal Matching Analyse. Anwendungen in den Sozialwissenschaften. Opladen: Leske and Budrich.

Althauser, R. P. (1989). Internal labor markets. Annual Review of Sociology, 15, 143-161.

Arthur, M. B. and Rousseau, D. M. (1996). The Boundaryless Careers. A New Employment Principal for a New Organizational Era. Oxford: Oxford University Press.

Baron, J. N. and Bielby, W. T. (1980). Bringing the firm back in: stratification, segmentation, and the organization of work. American Sociological Review, 45, 737-765.

Barrial, F. (2006). Evolution du profil sociologique de l'élite managériale Suisse entre 1980 et 2000, Mémoire de licence ès science politique. Lausanne: Université de Lausanne.

Becker, H. (1952). The career of the chicago public schoolteachers. American Journal of Sociology, 57, 470-477.

Becker, H. and Strauss, A. L. (1956). Careers, personality, and adult socialization. American Journal of Sociology, 62, 253-263.

Blau, P. and Duncan, O. D. (1967). The American Occupational Structure. New York: Wiley.

Boegli, L., Inversin, L., Müller, P. and Teichgräber, M. (2007). Studien- und Lebensbedingungen an den Schweizer Hochschulen. Neuchâtel: Office Féderal de la Statistique.

Boltanski, L. (1982). Les cadres. Paris: Minuit.

Boltanski, L. and Chiapello, E. (1999). Le nouvel esprit de capitalisme. Paris: Gallimard.

Bouffartigue, P. and Gadea, C. (2000). Sociologie des cadres. Paris: La découverte.

Bourdieu, P. (1979). La distinction. Paris: Minuit.

Capelli, P. (1999). Career jobs are dead. California Management Review, 42, 146-167.

Castel, R. (1999). Les métamorphoses de la question sociale: une chronique du salariat. Paris: Gallimard.

Dany, F. (2001). La carrière des cadres à l'épreuve des dispositifs de gestion. In Bouffartigue, P. (Ed.), Cadres: la grande rupture. Paris: La Découverte.

Doeringer, P. B. and Piore, M. (1971). Internal Labor Markets and Manpower Analysis. Lexington, MA: Heath.

Fligstein, N. (1987). The intraorganizational power struggle: rise of finance personnel to top leadership in large corporation, 1919-1979. American Sociological Review, 52, 44-58.

Gauthier, J.-A., Widmer, E., Bucher, P. and Notredame, C. (2008a). How much does it cost?
Optimization of costs in sequence analysis of social science data. Sociological Methods and Research (accepted).

Gauthier, J.-A., Widmer, E., Bucher, P. and Notredame, C. (2008b). Multichannel sequence analysis applied to social science data (under review).

Gunn, S. and Bell, R. (2003 [2002]). Middle Classes: Their Rise and Sprawl. London: Phoenix.

Honegger, C., Bühler, C. and Schallberger, P. (2002). Die Zukunft im Alltagsdenken. Szenarien aus der Schweiz. Konstanz: UVK.

Kelle, U. and Kluge, S. (1999). Vom Einzelfall zum Typus. Opladen: Leske and Budrich.

Kohli, M. (1985). Die Institutionalisierung des Lebenslaufs. Kölner Zeitschrift für Soziologie und Sozialpsychologie, 37, 1-29.

König, M., Siegrist, H. and Vetterli, R. (1985). Warten und Aufrücken. Die Angestellten in der Schweiz, 1870-1950. Zürich: Chronos.

Levy, R., Joye, D., Guye, O. and Kaufmann, V. (1997). Tous égaux? De la stratification aux représentations. Zürich: Seismo.

Mendras, H. (1988). La seconde révolution française. Paris: Gallimard.

Meyer, T. and Ryter, E. (1993). Ingenieurinnen und Ingenieure in der Schweiz: Ausbildung und Arbeitsmarkt. Bern: Bundesamt für Statistik.

Milligan, G. W. and Cooper, M. C. (1985). An examination of procedures for determining the number of clusters in a data set. Psychometrika, 50, $159-179$.

Mills, C.-W. (1951). White Collar. The American Middle Classes. New York: Oxford University Press.

Osterman, P. (Ed.), (1996). Broken Ladders. Managerial Careers in the New Economy. Oxford: Oxford University Press.

Power, M. (1997). The Audit Society. Rituals of Verifiction. Oxford: Oxford University Press.

Rosenbaum, J. E. (1979). Organizational career mobility. American Journal of Sociology, 85, 21-48.

Schnyder, G., Lüpold, M., Mach, A. and David, T. (2005). The Rise and Decline of the Swiss Company Network during the $20^{\text {th }}$ Century. Lausanne: Institut d'Etudes Politiques et Internationales (Travaux de science politique $\mathrm{N}^{\circ} 22$ ).

Sennett, R. (1998). The Corrosion of Character. The Personal Consequences of Work in the New Capitalism. New York: Norton.

Spilerman, S. (1977). Careers, labor market structure, and socioeconomic achievement. American Journal of Sociology, 83, 551-593. 
Stovel, K., Savage, M. and Bearman, P. (1996). Ascription into achievement: models of career systems at lloyd bank. 1890-1970. American Journal of Sociology, 102, 358-399.

Vester, M., Von Oertzen, P., Geiling, H., Hermann, T. et al. (2001). Soziale Milieus im gesellschaftlichen Strukturwandel: Zwischen Integration und Ausgrenzung. Frankfurt a/M: Suhrkamp.

Weber, M. (1972 [1921]). Wirtschaft und Gesellschaft. Grundrisse der verstehenden Soziologie. Tübingen: Mohr Siebeck.

Whyte, W. H. (1963 [1956]). The Organization Man. Harmondsworth: Pelican.

Widmer, E., Levy, R., Pollien, A. and Hammer, R. et al. (2003). Entre standardisation, individualisation et sexuation: une analyse des trajectoires personnelles en Suisse. Swiss Journal of Sociology, 29, 35-67.

Wilensky, H. L. (1961). Orderly careers and social participation: the impact of work history on social integration in the middle mass. American Sociological Review, 26, 521-539.

Wohlrab-Sahr, M. (1995). Erfolgreiche Biographie Biographie als Leistung. In Fischer-Rosenthal, W. and Alheit, P (Eds), Biographien in Deutschland: Soziologische Rekonstruktionen gelebter Gesellschaftsgeschichte. Opladen: Westdeutscher Verlag.

\section{Author's Address}

Institut interdisciplinaire d'études de trajectoires biographiques (ITB), Faculté des Sciences Sociales et Politiques, Bâtiment Vidy, University of Lausanne, CH-1015 Lausanne, Switzerland. Tel: 0041 (0)21 69238 49; Fax: 0041 (0)21 692 38 45; Email: felix.buhlmann@unil.ch

Manuscript received: February 2007 